\title{
Flood risk management in French Mediterranean basins
}

\author{
F. Vinet \\ Department of Geography, University of Montpellier III, France
}

\begin{abstract}
After severe flash floods that caused many fatalities a few years ago in the Mediterranean regions of France, the French government decided to help local authorities to reduce flood risk. Through the example of small basins in southern France, this paper shows the principles and the practises involved in mitigating flood risk. The flood risk management plans, established by river basin authorities, are subsidized both by the central government and by local authorities. They illustrate the progressive change of philosophy in flood management policy. The principles of flood risk management have changed through history from structural measures (dikes, embankments, dams) to non-structural methods (e.g., land-use planning, preparedness measures, reduction of vulnerability, early-warning systems, human collective memory and public awareness). The flood risk management policies are thus politically and technically integrated. This paper points out some of the reasons that can explain the success or the failure of flood risk reduction in a river basin. It shows how partisan politics can be an obstacle to the implementation of such plans. The last challenge is to evaluate the positive and negative effects of the flood-mitigation policies. This work finishes by proposing some indicators to evaluate the real effects of flood reduction.

Keywords: flash floods, flood management plans, Mediterranean basins, dikes.
\end{abstract}

\section{Introduction}

For twenty years, a change of paradigm in flood risk management has been spreading in many countries. This shift has been late in France (Pottier et al. [1]). Recent dramatic floods, revealing the failure of previous flood management policies, have obliged national and local authorities to change their point of 
view; since 2002 they have been implementing flood management plans in river basins. After an overview of the changing paradigm in flood management policies, this paper examines the actual implementation of flood management plans and underscores the difficulties that keep basin authorities from implementing some flood reduction measures.

\section{The changes of flood management frameworks after recent catastrophic floods}

\subsection{Recent floods in France}

The Mediterranean basin is familiar with spectacular flash floods. French Mediterranean regions are regularly hard-hit by intense rainfalls triggering fatalities and billions of euros in losses. Of course, the occurrence of such floods is irregular. After some decades without a significant event, many severe flash floods have occurred since the mid-1980s. In 1988, the city of Nimes suffered widespread flooding, and ten people died. In 1992, 42 people died during flash floods that particularly hurt Vaison-la-Romaine. The two determining flash floods, however, occurred in 1999 and 2002. The first event took place in the Aude and nearby departments on 12 and 13 November 1999. 35 people died, 35,000 houses were flooded and the amount of losses was evaluated up to 650 M€. Less than three years later, on 8 and 9 September 2002, the Gard department suffered 23 fatalities and losses exceeding one billion euros. In both cases, rainfalls exceeded $600 \mathrm{~mm}$ within 24 hours in some places.

Mediterranean watersheds are rather small. They spread out between $400 \mathrm{~km}^{2}$ (Touloubre) and $5000 \mathrm{~km}^{2}$ (Aude basin, fig. 1). Consequently, geo-hydrological conditions are quite similar and linked to topographical conditions. In upper basins, runoff begins on hills of altitudes from 500 to 1500 meters. Deep valleys, strong slopes and heavy rainfalls account for the fact that in small watersheds (less than $20 \mathrm{~km}^{2}$ ), the peak discharges exceeded $20 \mathrm{~m}^{3} \cdot \mathrm{s}^{-1} \cdot \mathrm{km}^{2}$ in the core of flooded zone in 2002 (Gaume et al. [2]). Hills are covered with deep brush that protects slopes from landslides. Such upper valleys are sparsely populated.

Down the hills, the valleys become larger and the flood-prone zone is 500 to $1000 \mathrm{~m}$ wide. Here are vineyard-covered "piedmonts" where the density of population is higher (50 to 100 habitants per $\mathrm{km}^{2}$ ).

Going downstream, the rivers run into low plains. The water streams more slowly (less than $1 \mathrm{~m} . \mathrm{s}^{-1}$ ) between dikes and the peak discharge usually arrives several hours, sometimes one day, after having affected the high parts of the watershed. The plains are wide and density is high (over 150 inhabitants per $\mathrm{km}^{2}$ ) due to the presence of many towns and tourist activities. In 1999 and 2002, many dikes failed, killing ten people and overwhelming hundreds of $\mathrm{km}^{2}$.

\subsection{The need for a changing framework in flood prevention}

Many flood reports in France had revealed the failure of flood management policies. Two major aspects had been criticized: flood warning and dike breaks. After the Gard flash floods in September 2002, many citizens criticized the 
mayors (the communes' elected authorities) before a tribunal, and several mayors criticized in turn the state authorities for lack of warning. As a result, the French government has been reorganizing flood warning and crisis management. Another polemical issue had been dike and levee management. The problem of dike maintenance is unfortunately well-known in many countries, e.g. Germany and the USA after Hurricane Katrina. Sometimes, floods overflow the dikes, but in many cases failure is due to bad maintenance. Dike owners are not always known, and even when they are identified (e.g., the communes, or private riverside owners), they may have insufficient resources to repair the dikes.

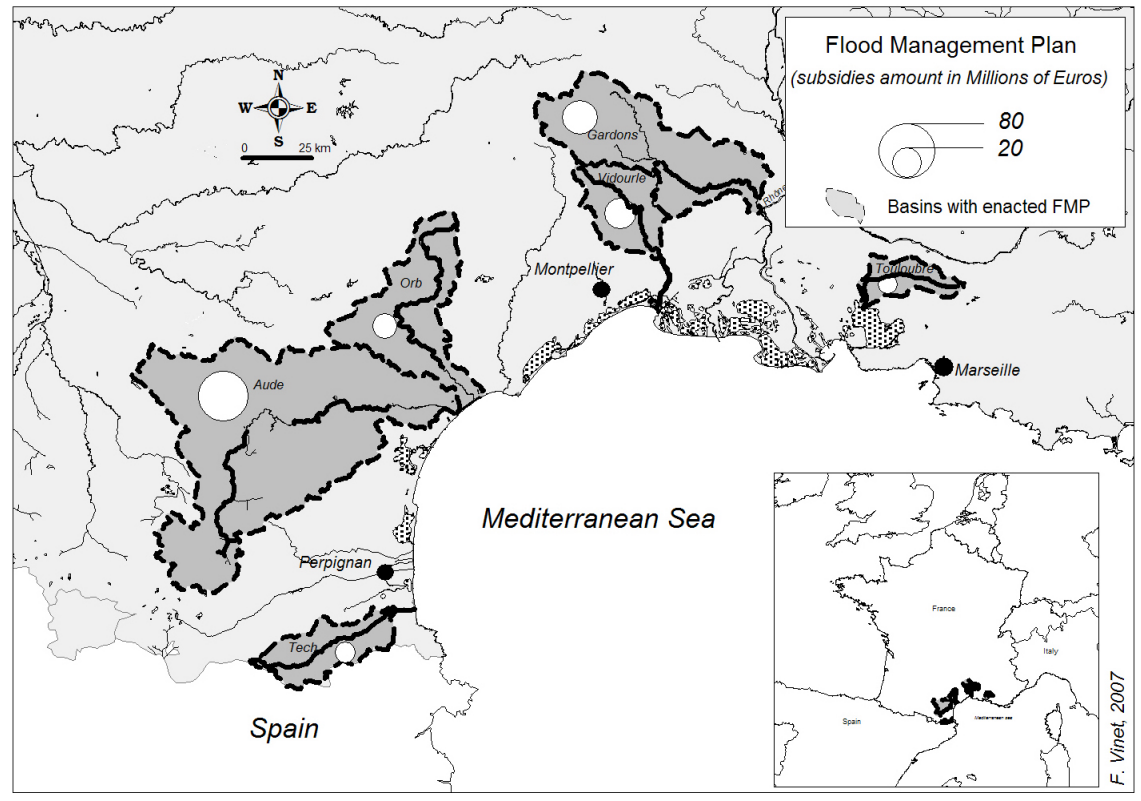

Figure 1: $\quad$ Flood Management Plans in French Mediterranean basins.

Another consequence of those floods is the demand on the part of citizens for more protection against floods. In the Vidourle basin, almost all the communes have been declared in a state of "natural disaster" according to governmental decrees. Thus, the flooding reinforced awareness of the risk and also increased the pressure upon the authorities. People want authorities to protect them from floods, and with concrete and visible results, as soon as possible.

The failure of $20^{\text {th- }}$ century flood management policies is observed not only in France, but also in other European countries, and in the USA. As Werritty [3] states, "A seismic shift is taking place in managing flood risk in many countries," but if current flood management frameworks are questioned (Gruntfest and Handmer [4]), the "seismic shift" is slow. There has been a single minded focus on structural measures. International organisations admit now that one must shift from defensive action against hazards to an integrated management of the risk (ISDR [5]; European Community [6]). 


\subsection{The call for flood management plans}

The Ministry of Ecology and Sustainable Development (MESD) decided to encourage local river basin authorities to mitigate flood risk. The circular of 1 October 2002, enacted three weeks after the catastrophic flash flood in the Gard, called for flood management projects based on several criteria: 1) to develop public awareness; 2) to create or to rehabilitate floodplain storage areas upstream in order to maintain solidarity between flood plains (often struck by floods) and upstream watersheds; 3 ) to reduce vulnerability and protect urban areas.

Between 2002 and 2004, river basin authorities throughout France elaborated flood management plans. MESD chose from among them on the basis of two principles: the high level of risk in the basin in question and the validity of the plan and credibility of the project as drawn up by the basin authority.

According to European Community recommendations (European Community, [6]), Flood Management Plans (FMP) must favour a holistic approach to flood prevention and must be established in integrated patterns: spatial and technical integration. Spatial integration means that the whole basin has to be affected by flood mitigation measures. Technical integration means that flood reduction may be achieved by either structural measures (dikes, flood storage areas) or non-structural measures (reduction of building vulnerability, development of public awareness of risk, crisis management). The chosen plans are granted $25 \%$ to $40 \%$ by MESD. Complementary subsidies are provided by regional and local authorities and by the river basin authorities themselves.

This call for projects reveals the changing attitude of the French government regarding risks. For many years, state authorities and communes had been the major actors in risk prevention. This pattern, however, had not been efficient, because communes dealt only with their own territory, without coherence in the watershed as a whole. Despite reassurances, state authorities lack the technical and political means to control everything in the field of risk management. The aim of these FMP is to empower river basin authorities, as they have an evident stake in the issue of flood management. Most of the river basin authorities have been in existence for some time, but they heretofore lacked the resources and the political strength to implement flood management programs. Now, the principle is to coordinate a hydrological unit (the watershed) with a political and technical unit, i.e., the river basin structure. The political entity is linked to the natural area. The aim of state authorities is to assure the long-term maintenance of works, especially dikes. As a result, the French state decided to stop paying for flood defence unless it was handled by river basin authorities.

\section{Flood prevention in river basins}

\subsection{Financial distribution of flood reduction measures}

We studied the distribution of budget estimates in six river basins holding a FMP accepted by MEDD (fig. 1). Of course, we can't assess all river basin authorities' policies on such plans because they led other actions apart from FMP. 
Nevertheless, the distribution of subsidies by item is significant as regards policy choices, especially between structural and non-structural measures (Table 1).

Table 1: Planned Investments for Flood Prevention in Flood Management Plans.

\begin{tabular}{cccccccc}
\hline item & $\begin{array}{c}\text { Vidourle } \\
\text { basin } \\
(2003-\end{array}$ & $\begin{array}{c}\text { Gardons } \\
\text { basin }\end{array}$ & $\begin{array}{c}\text { Tech } \\
\text { basin } \\
(2005- \\
2006)\end{array}$ & $\begin{array}{c}\text { Orb } \\
\text { basin } \\
(2003- \\
2010)\end{array}$ & $\begin{array}{c}\text { Touloubre } \\
\text { basin }(\text { end } \\
2003-\text { end } \\
2008)\end{array}$ & $\begin{array}{c}\text { basin } \\
(2006-\end{array}$ & $\begin{array}{c}\text { Total } \\
\left(10^{6} \text { Euros }\right)\end{array}$ \\
\hline $\begin{array}{c}\text { Program } \\
\text { charges }\end{array}$ & 0,72 & 0,00 & 0,141 & 0,5 & 0,312 & 0,49 & 2,16 \\
\hline $\begin{array}{c}\text { Public } \\
\text { information and } \\
\text { awareness }\end{array}$ & 0,845 & 0,92 & 0,39 & 0,3 & 0,04 & 0,72 & 3,25 \\
\hline $\begin{array}{c}\text { Forecast and } \\
\text { warning }\end{array}$ & 1,14 & 2,61 & 0,221 & 0,7 & 0,282 & 1,35 & 6,28 \\
\hline $\begin{array}{c}\text { Vulnerability } \\
\text { mitigation }\end{array}$ & 6,6 & 8,60 & 0,661 & 0,7 & 0,03 & 0,8 & 17,36 \\
\hline $\begin{array}{c}\text { Upstream flood } \\
\text { control }\end{array}$ & 9,97 & 16,95 & 2,29 & 5,9 & 11,22 & 41,43 & 87,81 \\
\hline $\begin{array}{c}\text { Collective } \\
\text { protection } \\
\text { (dikes and } \\
\text { floodwalls })\end{array}$ & 10,57 & 9,80 & 10,456 & 11,9 & 0 & 35,21 & 77,96 \\
\hline Total & $\mathbf{2 9 , 8 5}$ & $\mathbf{3 9}$ & $\mathbf{1 4 , 1 6}$ & $\mathbf{2 0}$ & $\mathbf{1 1 , 8 8}$ & $\mathbf{8 0}$ & $\mathbf{1 9 5}$ \\
\hline
\end{tabular}

These plans are clearly involved in structural measures. Dike maintenance and building constitute $40 \%$ of investments, and upstream flood storage areas $45 \%$. Therefore, actions on hazard control amount to $85 \%$ of financial resources, i.e., 166 of $195 \mathrm{M€}$. Forecast and warning may be considered apart, because this field depends on state core competencies. Reduction of vulnerability is little considered (between $0.1 \%$ to $5 \%$ of FMP subsidies) except in the Vidourle and Gardons projects, where this item is gratified with 6,6 M€ (22\%)

\subsection{Implementation of plans}

It should be noted first that flood management plans are not completely achieved even after three years. Even though the call for flood management plans was launched in 2002-2003, the implementation of these measures has often been delayed, for different reasons. State authorities have lengthened the deadline for the achievement of projects previously planned for three years. Nevertheless, measures of progress are not the same according the different issues described in Table 1. According to river basin authorities' annual reports, we can give a first appraisal of planned actions.

The information campaign directed to riverside populations has progressed, and is aided by the living memory of recent flash floods. Programs have been established in schools to inform the children about flood risk. River basin authorities help communes to implement local emergency plans. On the contrary, upstream flood storage basins are difficult to achieve in small watersheds where 
the benefits of such basins are not obvious. Even some river basin authorities' engineers are not convinced of their relevance. Likewise, projects for reducing individual vulnerability have been delayed, partly as a result of governmental authorities' reluctance. In fact, the first achievements of flood management plans are structural protections already planned before the acceptance of the plans by the MESD.

\subsection{Difficulties in fulfilment of flood Management Plans}

We can categorize three kinds of difficulties: technical and methodological challenges; juridical and financial uncertainty; and political and psychological opposition.

\subsubsection{Technical and methodological challenges}

Unless river basin structures are technically competent, some difficulties appear when implementing concrete measures to reduce flood risk. The first one is lack of data about flood hazard. Small watersheds have not undergone any flooding for a long time, and have not got any stream gauging network (Gaume et al. [2]). A more profound challenge is the lack of vulnerability assessment: vulnerability of housing, industries and flood-defence systems. The Tech and Aude valleys need to check their old embankment systems in the low plains. The heaviest problem is to define the property of dikes because, after the 1930 and 1940 floods, many dikes were built on private fields with public subsidies. River basin authorities have also implemented some studies to assess the vulnerability of housing and industries. Such studies have been undertaken for a long time in other countries, but they are more recent in France, having been initiated in the Loire basin (Ledoux and Sageris [7]). These studies are also an opportunity to sensitize people to vulnerability, which is often ignored. For example, they revealed the lack of know-how for camping emergency plans in the most tourist region of France.

\subsubsection{Juridical and financial uncertainty}

The juridical status of works is complicated. Existing works such as dikes or floodwalls belong to the proprietor and not to granter of subsidies. The long term status of works (dikes, flood storage areas) is not ensured, and this question is sufficiently uncertain that financial resources are not warranted for the future. FMP are paid by a consortium of local, regional and national authorities (department councils, regional councils, MESD and river basin authorities) and the financial backing for maintenance of the works is unsure. River basin authorities do not have their own tax income. They depend on subsidies.

\subsubsection{Political and psychological opposition}

The third kind of difficulty is of a political order. The first obstacle is opposition among river basin authorities (led by local political figures) and other local or regional authorities. For example, the president of the Tech basin authority in the Pyrenees (Fig. 1) is deeply rooted in his district but in opposition to departmental and regional authorities. This situation results in difficulties in obtaining 
subsidies. Another kind of political problem is opposition among river basin authorities when influent politicians (the mayors of two major towns, for example) are in strong opposition and use the river basin authorities as a point of contention. This is case in the Vidourle river basin for example.

Among the various difficulties, psycho-sociological preconceptions are not the easiest to overcome. Mental perceptions of floods are deeply rooted in people's minds. Surveys show that many people believe that keeping a clean rural system of drainage could reduce floods, whereas studies prove that the costbenefit ratio of such maintenance is not often interesting.

\section{Discussions}

Confronted with such difficulties, we must raise certain issues regarding the technical, territorial and political patterns of flood management in France and especially in regions prone to flash flooding.

\subsection{Is the river basin a good level to manage risk?}

The first question - as a geographer - is the optimal scale for flood management efficiency. The watershed unit is often argued to be the only frame of flood mitigation. Even if it is necessary to invest in dike rehabilitation, the need for new flood defence lines as planned in the Aude, Orb and Vidourle low plains is debatable. Moreover, the MESD's call for flood management projects in 2002 insisted on the need to develop upstream storage areas and storage basins. Many river basin authorities included such works in the plans, in order to satisfy the inhabitants of upstream communes, and to respond properly to the national 2002 call. In many cases, those basins are not achievable in reasonable financial and technical conditions. The consequences and the future maintenance of such basins are unknown.

On the other hand, flood reduction methods which are not directly linked to hazard, such as vulnerability mitigation for houses or industries can be applied apart from the watershed framework. Thus, if the river basin is a good framework for mitigating flood hazard, many actions can be taken without consideration of "basin solidarity".

\subsection{The cost-benefit approach is neglected in France}

Although many references exist and many studies were undertaken on this issue (Ledoux and Hubert [8]; De Blois and Wind [9]), the cost-benefit approach has not been put into practise in France. When MESD called for flood management plan projects in 2002, the cost-benefit analysis was not clearly required, although many plans contained an economic aspect. Difficulties in assessing long-term costs and benefits in flood management are certainly a handicap for this method, but many authors recommend this approach (DEFRA [10]). The French disaster insurance system is not geared to developing people's involvement in flood mitigation. France suffers from poor economic culture and the domination of political factors in decision making. For example, the cost-benefit ratio problem 
of flood storage basins has never been seriously addressed regarding small Mediterranean basins. While the hydrological benefits are small for huge floods, the cost of such basins may be assessed not only in financial terms (the cost of building and maintenance) but also in aesthetic terms in a tourist region. Leading authors (Gruntfest and Handmer [4]) think now that both land-use planning and warning systems are the most efficient measures to mitigate flash floods.

\subsection{A permanent atlas for flood prevention assessment}

Montz [11] notes that many studies appreciate the cost-benefit ratio of flash flood mitigation whereas few works give a historical analysis of mitigation measures. For this purpose, our laboratory is building a permanent atlas of natural risk in the French Mediterranean region. In this framework, the permanent atlas compiles both self-made indicators and existing databases. One of the numerous aims of this atlas is to assess long-term progress regarding flood prevention. The first range of indicators is related to hazard data. The second range of indicators deals with vulnerability and damage. The third concerns mitigation measures such as land use planning, structural investments, local emergency plans and warning systems. We have chosen to illustrate the possibilities of this atlas with two indicators of flood risk magnitude in the Orb basin. The first one (Fig. 2) uses the Gaspar database published by the MESD. We can see in the Orb basin that low plains are exposed (more than 10 decrees within 25 years).

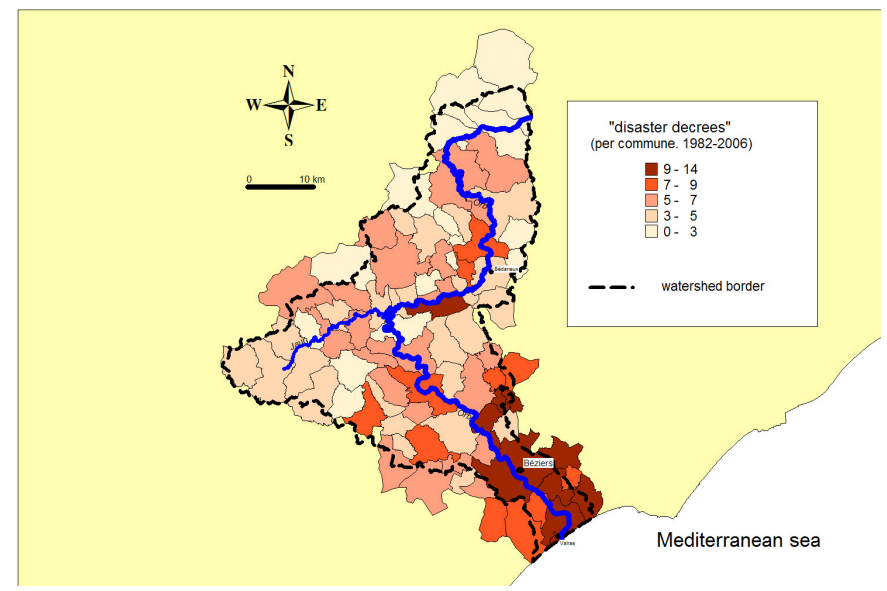

Figure 2: $\quad$ Number of Natural Disaster Decrees per commune in Orb basin.

The second map (Fig. 3) is derived from a database built by Antoine et al. [12] and completed since 1999 with our own data recording all fatalities due to floods in the French Mediterranean region. It shows that only 8 out of 23 fatalities took place in rivers concerned by the national flood warning system. It shows the need to recast Flood warning system in southern France as in many other countries (Khatibi et al. [13]). 


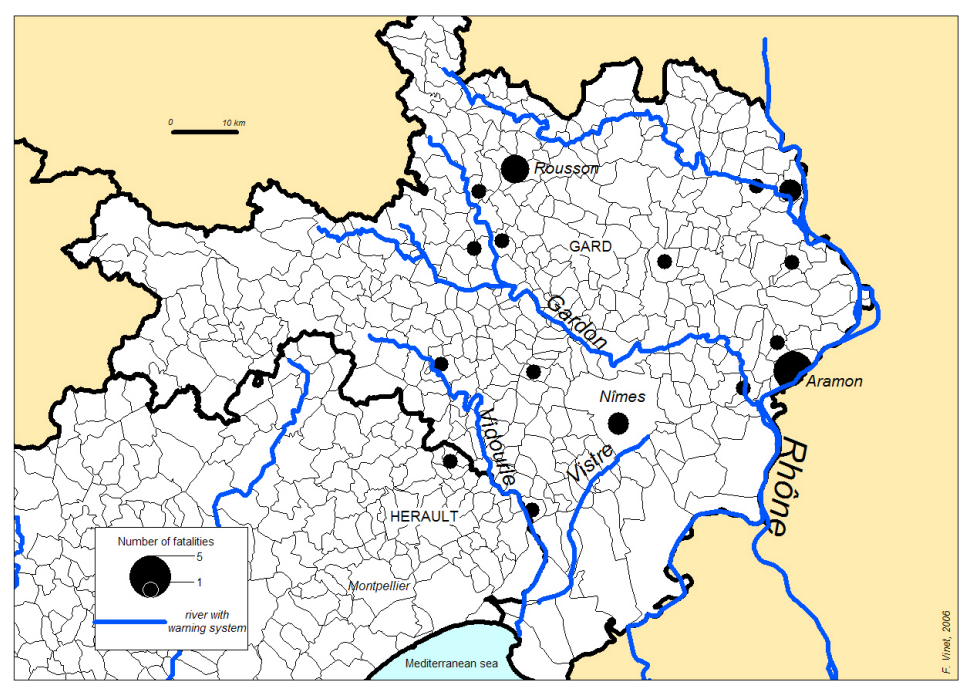

Figure 3: $\quad$ Fatalities and flood warning during the September 2002 floods.

\section{Conclusion}

The study of budget estimates of flood management plans in French Mediterranean rivers shows that the emphasis on structural measures is still very high. If some measures are on their way to being implemented (local emergency plans, for example, or some floodplain storage areas), the implementation of flood management will take a long time, exceeding the three-year deadline allotted by the French Minister of Ecology. It will take at least eight or ten years, although we suppose that some measures will never be achieved. Works to reduce individual vulnerability have been delayed for juridical and financial reasons.

The second conclusion is that unless flood management plans are involved in a nationwide process, the degree of achievement of these plans will vary widely among basins. The first condition for FMP to be achieved efficiently is that all those concerned locally must be involved and responsible in a local consensus. Presently, each configuration is different, and there is no magic formula to bring about flood management success. One of the major bottlenecks is the lack of awareness regarding the efficiency of certain measures such as upstream water storage, which is useful in large basins (e.g., the Rhine River) but hard to achieve, and not really efficient in small watersheds suffering from flash floods.

Despite delays in the achievement of flood management plans, the experience is slowly changing the attitude of affected citizens facing flood risk. Financial and political support by state authorities should continue so long as river basin authorities remain fragile. 


\section{References}

[1] Pottier N., Penning-Rowsell E., Tunstall S. \& Hubert G., "Land Use and Flood Protection: Contrasting Approaches and Outcomes in France and in England and Wales". Applied Geography, 25. 1-27, 2005.

[2] Gaume, E., Livet, M., Desbordes, M. \& Villeneuve, J. P., "Hydrological Analysis of the River Aude, France", flash flood on 12 and 13 November 1999. Journal of Hydrology. 286, pp. 135-154., 2004.

[3] Werritty A., Sustainable flood management: oxymoron or new paradigm? Area, 38-1, 16-23, 2006.

[4] Gruntfest E. \& Handmer J. eds., Coping with Flash Floods. NATO science series Kluwer Academic Publishers, 322 p., 1999.

[5] ISDR, Living with Risk: a Global Review of Disaster Reduction Initiatives. United Nations. Geneva. 382 p., 2002.

[6] European Community, Directive of the European Parliament and the Council on the Assessment and Management of Floods. Proposal paper, 20 p., 2006.

[7] Ledoux B., Sageris, Guide de la conduite des diagnostics des vulnérabilités aux inondations pour les entreprises industrielles, 126 p., 1999.

[8] Ledoux B., Hubert G., Le Coût du risque... L'évaluation des impacts socio-économiques des inondations. Presses de l'École nationale des ponts et chaussées. Paris, 231 p., 1999.

[9] De Blois C.J. \& Wind H.G., Assessment of Flood Damages and Benefits of Remedial Actions: "What Are the Weak Links?"; with Application to the Loire. Phys. Chem. Earth, vol. 20, N 5-6 pp. 491-495, 1995.

[10] DEFRA/Environment Agency, Flood Risk to People: Phase 1, 123 p., 2003.

[11] Montz B.E., "Assessing the Effects and Effectiveness of Flash Flood Mitigation Strategies" in Gruntfest E. and Handmer J. eds. Coping with Flash Floods. NATO science series, Kluwer Academic Publishers, pp. 123-134, 1999.

[12] Antoine J.M., Desailly B. \& Gazelle F., «Les Crues meurtrières, du Roussillon aux Cévennes ». Annales de géographie, n 622, p. 597-623, 2001.

[13] Khatibi R., Haggett C., Cook L., Haywood J., Jackson D. \& Kerman M., Towards best practise in flood warning. In Brebbia C.A. (Ed.) River Basin Management II, WIT Press pp. 331-340., 2003. 